\title{
An Analysis of Twitter Usage Among Startups in Europe
}

\author{
Sergej Lugović \\ Polytechnic of Zagreb \\ Vrbik 8, Zagreb, Croatia \\ lugovicsergej@gmail.com \\ Wasim Ahmed \\ Health Informatics Research Group, Information School, \\ University of Sheffield \\ Sheffield, UK \\ Wahmed1@sheffield.ac.uk
}

\section{Summary}

Startups are becoming part of the development of policies by the European Commission and corporate strategies. The business press widely covers startups, as does the other media. Local governments in Europe are also developing financial and administrative programs to support startups. Most industries now use social media, and in particular Twitter, to reach their customers. Twitter provides startups the opportunity to reach a global audience at a relatively low cost and still support both promotion and branding.

However, there's a lack of evidence-based research, which examines the Twitter usage among startups within the European Union (EU). This paper outlines preliminary findings about Twitter usage among EU startup founders and contributes to an ongoing study that seeks to define the concept of a startup.

Exploring Twitter usage among European startup founders could provide insight into their behavior and expand overall knowledge of how to best define the concept of a startup. The authors retrieved data used in the analysis from one of the most extensive EU databases, F6S.com. The authors collected the Twitter data user handles of EU startups in June and August 2015 and manually verified each Twitter account, which allowed the retrieval of data. The authors then entered the verified data (i.e., verified Twitter accounts) into the Twitter Archiving Google Sheets (TAGS) system that collected data for the purpose this longitudinal study.

The results of this research provide insight into temporal dynamics of Twitter usage, including Twitter account creation, followers, and tweets. There are statistically significant correlations between the Twitter activity of EU startups and the invested amount in that country overall and per capita. This paper offers a methodological contribution in regard to the social media data retrieval 
techniques, which can provide an insight into Twitter usage among EU startups founders.

Keywords: Twitter, Technology Entrepreneurship, Startup, Information Behavior, Big Data

\section{Introduction}

The Financial Times (McLannahan, 2015) recently published an article about Twitter usage as a source of valuable data for the financial industry. Investors using reports based on Twitter data could gain up to two-and-a-half percent when China Black Monday (Phillips \& Farrell, 2015) occurred. The main difference between Twitter and other social media data is that user-generated content is publicly available and is more easily accessible (Ahmed, 2015) because of Twitter's free API ecosystem. Twitter usage for the purpose of entrepreneurial activities is not just limited to marketing activities or as a medium of communication but also to support the whole process from opportunity recognition to bringing those opportunities to life (Fischer \& Reuber, 2011).

Twitter has the potential to open new opportunities because of its global reach and low cost, and it can support promotion and branding since it enables community interactions. Moreover, by using Twitter, it's possible to observe the competition and industry, more generally, by analyzing streams of tweets. Twitter is also useful for better understanding and engaging with customers (including customer support) (Curran at al. 2012).

Twitter has more than 316 million monthly active users, and there are more than 500 million tweets per day (Twitter.com, n.d.). Most companies acknowledge the importance of social media platforms: 93 percent declare that they employ social media in their marketing strategy, Facebook is top-rated (92\%), followed by Twitter (84\%) and LinkedIn (71\%) (Stelzner, 2011). Twitter is also useful as a tool integrated into product development, marketing communication, and recruitment (Savulescu \& Mihalcea, 2013). Small and medium-sized enterprises (SMEs) are, on one hand, drivers of the EU economy employing the majority of the people and creating the most value, and, on the other hand, have limited resources (ec.europa.eu, 2015). According to Wamba \& Carter (2013), there's a statistically significant relationship between a firm's innovativeness and the adoption of Twitter.

Another important aspect of using Twitter is its usage in investor relations (IR). IR is a strategic management responsibility that's integrated into finance, communication, marketing, and law compliance to enable two-way communications between company, the financial community, and other stakeholders. It contributes to a company's security to achieve fair valuation (niri.org, 2015). According to Coe (2013), investors match the take-up on social media by companies, and social media has the potential to move financial markets. The same report noted that professional investor use of Twitter usage is increasing, 63 percent of 
finance professionals (including brokers and heads of trading desks) believe that valuation of individual stocks can directly link to public sentiment contained in social media channels and 63 percent of 800 publicly traded companies use Twitter for investor-related activities.

Palanissamy (2014) suggested that three out of five financial bloggers use Twitter as their primary news source. Additionally, Twitter usage in investor relationships is also supported; Joyce (2013) noted that Twitter is the most widely used channel for IR, and that 72 percent out of 890 companies surveyed used Twitter to communicate investment materials in 2013. Another study (niri.org, 2013) found that investors viewed financial blogs, along with LinkedIn and Twitter, as the most valuable social media resources. The literature presented above indicates that companies for the purpose of IR use Twitter. Venture capital funds in the EU are increasing activity (Grilli \& Murtinu, 2014). At the same time, "startup" as a phenomenon is mentioned frequently within the media (ft.com, 2015), within political speeches, and European commission programs (ec.europa.eu, 2015). However, there's still no clear definition of what a startup is. On one side of the spectrum it's the definition used by the Ewing Marion Kauffman Foundation (Morelix et al., 2015) stating that "Startup businesses here are defined as employer firms less than one year old employing at least one person besides the owner."

On the other side of the spectrum, there's a definition by NESTA (Dee at al., 2015) that defines startups as "[A] young, innovative, growth-oriented business (employees/revenue/customers) in search of a sustainable and scalable business model." This definition expands on Steve Blank's (2013) definition of startups as organizations formed to search for repeatable and scalable business models.

According to NESTA, the emphasis is on defining startups as young companies. They differ from overall SMEs and need to develop different policies to support young companies and different ones to support small firms. Therefore, there's no consensus on what a startup is and what it does. Instead of seeking a definition, it's necessary to look at what those companies are doing. Such an inquiry aligns with the Low and MacMillan (1988) suggestion that research into entrepreneurial behavior should consider contextual issues and identify the processes that explain rather than merely describe the entrepreneurial phenomenon.

Cybernetics does not ask, "What is this?" but instead it asks, "What does it do?" It doesn't consider objects; rather, it considers the ways of behaving (Ashby, 1957). So, what companies actually do is the result of their founders' action. This paper examines the correlation of the Twitter usage of startup founders across the EU with the total country investment in startups in order to ascertain the extent to which we can predict how the startups will behave in the future. 


\section{Methodology}

The authors retrieved the data for the purpose of the research in the following way. First, they retrieved data related to EU startup founders from one of the most widely used databases, F6S.com, which has more than 110,000 companies in the database and 2 million unique visitors a month (f6s.com, 2015). In total, the authors retrieved 50,433 founders from 29 EU countries (including Norway), with the assistance of four freelance workers hired through the Upwork platform (Upwork.com, n.d.). There were more records in total; however, some founders related to more than one company, so the data set had to be de-duped (i.e., the removal of duplicates). Registering founders had the option to submit a company Twitter account and personal Twitter account. For the purpose of this research, the authors focused on the personal Twitter accounts the founders submitted.

After the identifying the Twitter accounts, the authors retrieved data from the accounts, in particular, the date the founders joined Twitter, how many tweets they posted, how many accounts they were following, and how many followers they had, in total 15,192 accounts. We also classified whether an account was private for the purpose of this study, and this was inferred from whether the founder submitted it as a private Twitter account. The authors retrieved data from twenty-nine countries from the EU, including Norway.

In parallel, the analytical company Funderbeam (2015) provided the financial data addressing EU-wide startup investments. This financial data broke down into investment per capital per country and total amount of investment in the startup ecosystem per particular country. Further, we selected Twitter accounts that had more than one hundred tweets and then more than one hundred followers. Those accounts, when filtered, were entered into the retrieval system Twitter Arching Google Sheets (TAGS) (Hawksey, 2013), which the researchers set to retrieve data on daily basis from those accounts. In total, there are 9,696 startup founders that have more than one hundred tweets and more than one hundred followers, and the accounts went into the TAGS system. The data retrieval period was from July 15, 2015 to September 9, 2015.

For the purpose of this preliminary analysis, the following hypotheses were formulated.

H1 Median time spent on Twitter of total country startup founders will have a statistically significant positive correlation with a) total investment in that country and b) investment per capita.

H2 Median number of tweets of total country startup founders will have a statistically significant positive correlation with a) total investment in that country and b) investment per capita.

H3 Median number of followers of total country startup founders will be a statistically significant positive correlation with a) total investment in that country and b) investment per capita. 
H4 Number of startup founders with more than one hundred tweets and followers per country will be a statistically significant positive correlation with a) total investment in that country and b) investment per capita.

H5 Percentage of total number of startup founders in the F6S.com database will be a statistically significant positive correlation with a) total investment in that country and b) investment per capita.

The results are presented in following section, including breakdown per country and correlations related to hypothesis.

\section{Results}

Results of our analysis are provided below. Table 1 presents overall results, including a breakdown to a country level, including total number of companies in the F6S.com database, the number of founders with Twitter accounts, the percentage of those who submitted their personal Twitter account to F6S.com, the number of startup founders with more than one hundred tweets and followers, the median number of days spent on Twitter, the number of tweets posted, the number of followers, and the number the founders followed. Table 2 presents correlations that align with the hypothesis mentioned earlier in the text.

Table 1. Overview of collected data

\begin{tabular}{|l|r|r|r|r|r|}
\hline & $\begin{array}{c}\text { Total no. in } \\
\text { F6S.com }\end{array}$ & $\begin{array}{c}\text { No. of Twitter } \\
\text { users }\end{array}$ & \multicolumn{1}{c|}{ \% } & $\begin{array}{c}\text { No. more than } \\
\text { 100 tweets \& } \\
\text { more than 100 } \\
\text { followers }\end{array}$ & $\begin{array}{c}\text { Median no. of days } \\
\text { on Twitter }\end{array}$ \\
\hline Austria & 505 & 130 & 25.74 & 70.00 & $2,193.0$ \\
\hline Belgium & 1,031 & 336 & 32.59 & 245.00 & $2,049.0$ \\
\hline Bulgaria & 2,970 & 466 & 15.69 & 225.00 & $1,973.0$ \\
\hline Croatia & 452 & 135 & 29.87 & 74.00 & $1,737.5$ \\
\hline Cyprus & 184 & 40 & 21.74 & 20.00 & $1,864.0$ \\
\hline Czech & 611 & 144 & 23.57 & 66.00 & $1,925.0$ \\
\hline Republic & 694 & 183 & 26.37 & 115.00 & $2,004.0$ \\
\hline Denmark & 1,303 & 152 & 11.67 & 77.00 & $2,164.0$ \\
\hline Estonia & 1,135 & 302 & 26.61 & 159.00 & $2,022.0$ \\
\hline Finland & 5,000 & 1,788 & 35.76 & $1,136.00$ & $1,922.0$ \\
\hline France & 3,416 & 872 & 25.53 & 518.00 & $2,107.0$ \\
\hline Germany & 957 & 270 & 28.21 & 154.00 & $1,897.0$ \\
\hline Greece & 756 & 127 & 16.80 & 64.00 & $2,020.5$ \\
\hline Hungary & 1,944 & 738 & 37.96 & 518.00 & $1,882.0$ \\
\hline Ireland & 4,851 & 1,347 & 27.77 & 781.00 & $1,790.0$ \\
\hline Italy & 321 & 78 & 24.30 & 54.00 & $2,162.0$ \\
\hline Latvia & 468 & 76 & 16.24 & 41.00 & $1,977.0$ \\
\hline Lithuania & & & & & \\
\hline
\end{tabular}


INFuture2015: e-Institutions - Openness, Accessibility, and Preservation

\begin{tabular}{|l|r|r|r|r|r|} 
Luxembourg & 108 & 30 & 27.78 & 22.00 & $1,769.0$ \\
\hline Malta & 53 & 15 & 28.30 & 12.00 & $1,848.5$ \\
\hline Netherlands & 2,366 & 737 & 31.15 & 493.00 & $1,852.0$ \\
\hline Poland & 913 & 183 & 20.04 & 82.00 & $1,530.5$ \\
\hline Portugal & 1,582 & 364 & 23.01 & 113.00 & $2,204.0$ \\
\hline Romania & 1,192 & 296 & 24.83 & 138.00 & $2,039.0$ \\
\hline Slovakia & 291 & 87 & 29.90 & 44.00 & $1,927.0$ \\
\hline Slovenia & 533 & 128 & 24.02 & 64.00 & $1,939.5$ \\
\hline Spain & 4,917 & 1,832 & 37.26 & $1,318.00$ & $\mathrm{~N} / \mathrm{A}$ \\
\hline Sweden & 701 & 190 & 27.10 & 114.00 & $2,043.0$ \\
\hline UK & 11,033 & 4,102 & 37.18 & $2,954.00$ & $2,042.0$ \\
\hline
\end{tabular}

Table 1 continued

\begin{tabular}{|l|r|r|r|r|r|}
\hline & $\begin{array}{c}\text { Median no. of } \\
\text { tweets }\end{array}$ & $\begin{array}{c}\text { Median no. } \\
\text { following }\end{array}$ & $\begin{array}{c}\text { Median no. } \\
\text { followers }\end{array}$ & $\begin{array}{c}\text { Amount of } \\
\text { money per } \\
\text { capita } \\
\mathbf{0 7 / 2 0 1 4} \\
\mathbf{0 7 / 2 0 1 5}\end{array}$ & $\begin{array}{c}\text { Investment per } \\
\text { country }\end{array}$ \\
\hline Austria & 453.5 & 238.0 & 134.0 & 2.64 & $255,566,415$ \\
\hline Belgium & 482.0 & 314.5 & 282.5 & 4.35 & $298,527,566$ \\
\hline Bulgaria & 267.0 & 150.0 & 109.0 & 0.45 & $31,029,533$ \\
\hline Croatia & 346.0 & 229.0 & 160.0 & 0.16 & $3,733,794$ \\
\hline Cyprus & 210.0 & 164.0 & 97.0 & 46.18 & $93,175,435$ \\
\hline Czech & 283.0 & 128.0 & 96.0 & 0.62 & $18,244,152$ \\
Republic & 469.0 & 260.0 & 195.0 & 26.97 & $494,836,809$ \\
\hline Denmark & 284.0 & 188.5 & 126.0 & 41.79 & $131,018,985$ \\
\hline Estonia & 239.0 & 231.0 & 124.0 & 30.43 & $470,570,350$ \\
\hline Finland & 369.0 & 246.0 & 180.0 & 8.26 & $2,617,622,183$ \\
\hline France & 363.5 & 229.0 & 155.0 & 24.42 & $5,274,327,168$ \\
\hline Germany & 366.5 & 264.5 & 186.5 & 1.16 & $27,057,929$ \\
\hline Greece & 321.5 & 151.0 & 94.5 & 0.24 & $23,577,952$ \\
\hline Hungary & 534.5 & 392.0 & 802.6 & 37.21 & $801,443,259$ \\
\hline Ireland & 377.0 & 228.5 & 144.0 & 1.17 & $492,868,478$ \\
\hline Italy & 745.5 & 241.0 & 206.0 & 8.41 & $34,484,729$ \\
\hline Latvia & 270.5 & 169.5 & 139.0 & 2.35 & $98,813,906$ \\
\hline Lithuania & 414.0 & 303.0 & 191.0 & 38.77 & $65,648,950$ \\
\hline Luxembourg & 233.5 & 237.0 & 109.0 & $\mathrm{~N} / \mathrm{A}$ & 936,279 \\
\hline Malta & 217.5 & 255.0 & 214.5 & 19.47 & $2,254,461,161$ \\
\hline Netherlands & 199.0 & 109.0 & 0.82 & $208,804,181$ \\
\hline Poland & 184.0 & 113.0 & 1.96 & $64,947,960$ \\
\hline Portugal & & & & \\
\hline & & & & & \\
\hline
\end{tabular}


S. Lugović, W. Ahmed, An Analysis of Twitter Usage Among Startups in Europe

\begin{tabular}{|l|r|r|r|r|r|}
\hline Romania & 178.0 & 138.0 & 97.0 & 0.06 & $14,857,154$ \\
\hline Slovakia & 256.0 & 169.0 & 123.0 & 0.62 & $5,754,056$ \\
\hline Slovenia & 316.0 & 164.5 & 131.0 & 0.20 & $14,769,623$ \\
\hline Spain & 654.5 & 293.5 & 237.0 & 5.00 & $798,464,239$ \\
\hline Sweden & 479.5 & 239.5 & 197.0 & 32.86 & $1,210,577,278$ \\
\hline UK & 604.0 & 353.0 & 289.0 & 49.49 & $12,168,393,685$ \\
\hline
\end{tabular}

Table 2. Correlations

\begin{tabular}{|c|c|c|c|c|}
\hline \multicolumn{2}{|l|}{ H1a \& H1b } & $\begin{array}{c}\text { Days on } \\
\text { Twitter (M) }\end{array}$ & $\begin{array}{c}\text { H1b - Invest per } \\
\text { capita }\end{array}$ & $\begin{array}{c}\text { H1a }- \text { Invest per } \\
\text { country }\end{array}$ \\
\hline \multirow{3}{*}{$\begin{array}{l}\text { Days on } \\
\text { Twitter (M) }\end{array}$} & Pearson Correlation & 1 & -.152 & .098 \\
\hline & Sig. (2-tailed) & & .499 & .664 \\
\hline & $\bar{N}$ & 22 & 22 & 22 \\
\hline \multicolumn{2}{|l|}{ H2a \& H2b } & $\begin{array}{c}\text { H2b }- \text { Invest } \\
\text { per capita }\end{array}$ & $\begin{array}{c}\text { H2a }- \text { Invest per } \\
\text { country }\end{array}$ & No. of tweets (M) \\
\hline \multirow{3}{*}{$\begin{array}{l}\text { No. of tweets } \\
\text { (M) }\end{array}$} & Pearson Correlation & .057 & .356 & 1 \\
\hline & Sig. (2-tailed) & .776 & .063 & \\
\hline & $\mathrm{N}$ & 27 & 28 & 28 \\
\hline \multicolumn{2}{|l|}{ H3a \& H3b } & $\begin{array}{c}\text { H3b }- \text { Invest } \\
\text { per capita }\end{array}$ & $\begin{array}{c}\text { H3a }- \text { Invest per } \\
\text { country }\end{array}$ & Followers (M) \\
\hline \multirow{3}{*}{ Followers (M) } & Pearson Correlation & .328 & .200 & 1 \\
\hline & Sig. (2-tailed) & .095 & .308 & \\
\hline & $\mathrm{N}$ & 27 & 28 & 28 \\
\hline \multicolumn{2}{|l|}{ H4a \& H4b } & $\begin{array}{c}\text { H4b }- \text { Invest } \\
\text { per capita }\end{array}$ & $\begin{array}{c}\mathbf{H 4 a} \text { - Invest per } \\
\text { country }\end{array}$ & $\begin{array}{l}\text { No. more than } 100 \\
\text { tweets \& more } \\
\text { than } 100 \text { followers }\end{array}$ \\
\hline \multirow{3}{*}{$\begin{array}{l}\text { No. more than } \\
100 \text { tweets \& } \\
\text { more than } 100 \\
\text { followers }\end{array}$} & Pearson Correlation & .162 & .872 & 1 \\
\hline & Sig. (2-tailed) & .419 & .000 & \\
\hline & $\mathrm{N}$ & 27 & 28 & 28 \\
\hline \multicolumn{2}{|l|}{ H5a \& H5b } & $\begin{array}{c}\text { H5b }- \text { Invest } \\
\text { per capita }\end{array}$ & $\begin{array}{c}\text { H5a } \text { - Invest per } \\
\text { country }\end{array}$ & $\begin{array}{c}\% \text { having Twitter } \\
\text { acc in F6S }\end{array}$ \\
\hline \multirow{3}{*}{$\begin{array}{l}\% \text { having } \\
\text { Twitter acc in } \\
\text { F6S }\end{array}$} & Pearson Correlation & .036 & .410 & 1 \\
\hline & Sig. (2-tailed) & .860 & .030 & \\
\hline & $\overline{\mathrm{N}}$ & 27 & 28 & 28 \\
\hline
\end{tabular}

\section{Discussion}

As the results in Table 2 demonstrate, only two hypotheses are acceptable, H4a showing statistically significant correlations between total number of the startup founders who have more than one hundred tweets and more than one hundred followers with the total investment per country and H5a showing statistically significant correlations between percentage of the startup founders with personal Twitter profiles presented in the F6S database and total country investment. Rejection of other hypotheses could be interpreted that the average quantity of the tweets, followers, those the founders followed, and period spent on 
Twitter per country do not have an impact on the size of the investment startups receive and distribution of investment per capita.

Therefore, it isn't about how much is tweeted, however it could relate to the country level of Twitteracy (Greenhow \& Gleason, 2012). Within the startup ecosystem, much more importance was given to the founders' characteristics than to company traction (sales volume and user base) and other investors already invested.

A recent field experiment by Bernstein, Korteweg, \& Laws (2015) showed that average investors when looking for information about startups strongly respond to the founding team but not to firm traction or lead investors. Recently published research (Tata et al., 2015) used data from Twitter accounts of startup founders and analyzed the content of their tweets in relation to funding raised (in particular, they analyzed the temporal focus of tweets and how they related to startup performance). They found relations between tweets content and startup performance, including funding raised. The results demonstrate that high past focus, low future focus, high collective self-categorization, and lower level construals can associate with better performance.

Findings from this research, in particular, collective self-categorization, align with our findings, showing that size of the country ecosystem of startup founders is in positive correlation with country investment. The stronger the country's Twitter community is the more the country receives in funding. Lack of significant correlation between number of tweets, followers/following, and days spent on Twitter lead the authors to question relevance of the content created and distributed over Twitter to the investors. This is something that needs further exploration and in more depth.

The results presented in this paper support the direction of this research project, since there's evidence that data about Twitter usage could provide insight into the performance of a startup in terms of financial results. The hypotheses presented in this paper are put forward on a macro level (correlating within EU countries), and a micro level (individual founders' accounts) analysis has to be explored and analyzed in the next phase of the research.

An additional limitation is that the authors did not analyze content of the tweets and did not look into the reasons why some countries perform better than others in term of Twitter. The research had limits because only one source retrieved data for analysis (F6S.com). Also, the authors analyzed only the founders' private Twitter accounts and used only one source of financial data.

A more comprehensive study may use a variety of databases. However, this may not be feasible since the numbers gathered could become difficult to manage. In this paper, we presented preliminary results from the initial data gathered, but the data were only the starting point for a longitudinal study that is currently underway.

The authors believe that the dynamics of the founders' Twitter activities could correlate with startup performance (i.e. growth of the number of followers when 
compared with performance). Still, in order be in a position to infer this, data gathered over a longer period of time will have to be used and analyzed. Moreover, future research aims to conduct a more extensive statistical analysis of the data set that's collected. Additional methods of analysis may include sentiment analysis, network analysis, and the correlation of Twitter data with the companies' income. Further research may also explore even further the correlation with Twitter data with another social media channel, for example, Facebook or LinkedIn, or data such as the companies' Wikipedia pages and the number of visitors to the websites of the startups.

\section{Conclusion}

The findings demonstrate that it's possible to achieve great insight into the behavior of an object of interest by using indirect observation, in this instance observing Twitter data indirectly. However, to do so, the analysis has to dig deeper into the large amount of unstructured data processed by using advanced techniques. The authors plan to employ more advanced data mining and computational methods of analyzing the data gathered. Moreover, the research continues to collect data on a continuing basis from the 9,696 startup founders (Twitter accounts), which could provide insight into different aspects of startup as a phenomenon.

These findings and contemporary research methods could apply to different disciplines, such as information science, social media, entrepreneurship, and investors' relationship management. In addition, there's an outline of a robust methodology of capturing and analyzing Twitter data related to specific Twitter accounts.

\section{Acknowledgments}

The authors would like to thank Kaidi, Villu, and Nicholas from Funderbeam. com for providing the financial data used in this research paper.

\section{References}

About Startup Europe (n.d.). [Online] Retrieved from http://ec.europa.eu/digital-agenda/en/aboutstartup-europe [Last Accessed 19/09/15]

Ahmed, W., (2015). Using Twitter as a data source: An overview of current social media research tools. LSE Impact of Social Sciences blog Retrieved from http://blogs.lse.ac.uk/impactof socialsciences/2012/04/19/blog-tweeting-papers-worth-it/ 10 July 2015 (Last Accessed 11/07/ 2015).

Ashby, W. Ross, An introduction to cybernetics. Chapman \& Hall Ltd, London, 1957.

Bernstein, S., Korteweg, A. G., \& Laws, K. (2014). Attracting early stage investors: Evidence from a randomized field experiment. Rock Center for Corporate Governance. Stanford University working paper, (185), 14-17.

Blank, S., (2013). Why the lean start-up changes everything. Harvard Business Review, $91(5), 63-72$.

Coe, D. Companies and shareholder engagement-making the most of social media. Keeping Good Companies, (2013), 65(5), 307. 
Curran, K., O'Hara, K., \& O'Brien, S. (2012). The role of Twitter in the world of business. WebBased Multimedia Advancements in Data Communications and Networking Technologies, p. 169. http://scisweb.ulster.ac.uk/ kevin/twitter.pdf.

Dee, N., Gill, D., Weinberg, C., and McTavish, S. (2015). Startup support programmes: What's the difference? NESTA.

Fischer, E., \& Reuber, A. R. (2011). Social interaction via new social media: (How) can interactions on Twitter affect effectual thinking and behavior? Journal of Business Venturing, (2011) 26(1), 1-18. http://ntucriticalinquiry.wikispaces.com/file/view/Social+interaction+via+new+ social + media.pdf.

F6S.com (n.d.). [Online] Retrieved from: https://www.f6s.com/f6s [Last Accessed 19/09/15].

FT.com (n.d.). [Online] Retrieved from http://www.ft.com/intl/topics/themes/Tech_start-ups [Last Accessed 19/09/15].

Funderbeam.com. (n.d.). [Online] Retrieved from https://www.funderbeam.com/[Last Accessed 19/09/15].

Greenhow, C., \& Gleason, B. (2012). Twitteracy: Tweeting as a new literacy practice. In The Educational Forum 76(4) 464-478. Taylor \& Francis Group.

Grilli, L., \& Murtinu, S. (2014). Government, venture capital and the growth of European hightech entrepreneurial firms. Research Policy, 43(9), 1523-1543.

Hawksey, M. (2013). Twitter Archiving Google Spreadsheet (TAGS) v5. JISC CETIS MASHe: The Musing of Martin Hawksey (EdTech Explorer) https://tags.hawksey.info/ [Last Accessed $19 / 09 / 15]$.

Joyce, S., (2013). Public company use of social media for investor relationship http://q4web systems.com/files/doc_downloads/whitepapers/Q4-Web_2013-Blog-Whitepaper_FINAL.pdf Retrieved 14.09.2014. [Last Accessed 19/09/15].

Low, M. B., \& MacMillan, I. C. (1988). Entrepreneurship: Past research and future challenges. Journal of Management, 14(2): 139-161.

Morelix, A., Reedy, E. J., \& Russell, J. (2015). The startup activity national trends. Ewing Marion Kauffman Foundation.

McLannahan, B. (2015). In search of market signals amid Twitter noise, Financial Times 9 http://www.ft.com/intl/cms/s/2/99a7e7ec-4fea-11e5-8642-53585f2cfcd.html\#axzz3ly52ANif. Retrieved 15.09.2015.

Niri.org (2013). (http://www.niri.org/media/News-Releases/NIRI-and-Corbin-Perception-Release -Studies-of-Social-Media-Use-in-Corporate-Investor-Communications-.aspx Retrieved 15.09.2015

Palanissamy, A. (2014). Investor-relations-integrating social media into board - Oman perspective. European Journal of Business and Management 6(24), 108-113.

Phillips, T, Farrell, S., (2015). FTSE 100 loses more than £60bn after China’s 'Black Monday', The Guardian, $8 \mathrm{http} / / /$ www.theguardian.com/business/2015/aug/24/black-monday-chinesestock-market-loses-all-gains-since-start-of-year. Retrieved 14.09.2015.

Savulescu, R. M., \& Mihalcea, A. D. (2013). Social networking sites: Guidelines for creating new business opportunities through Facebook, Twitter and LinkedIn. Management Dynamics in the Knowledge Economy 1(1), 39-53.

SMES EC.Europe.eu http://ec.europa.eu/growth/smes/ Retrieved 15.09.2015.

Stelzner, M. A. (2011). Social media marketing industry report. How marketers are using social media to grow their businesses. Retrieved from http://www.socialmediaexaminer.com/ SocialMediaMarketingIndustryRe- port2012.pdf.

Tata, A., Martinez, D. L., \& Brusoni, S. (2015). Looking backward and forward? Understanding the role of temporal focus on startup performance Paper to be presented at DRUID15, Rome, 15-17, http://druid8.sit.aau.dk/druid/acc papers/xvmf701rrol2amebcmt1b8pemo94.pdf.

Twitter.com About, (n.d.). About Twitter, Inc. [Online] Retrieved from: https://about.twitter. com/company [Last Accessed 29 Mar. 2015].

US National Investor Relationship Institute (2015). [Online] Retrieved from http://niri.org/ FunctionalMenu/About.aspx [Last Accessed 19/09/15].

Upwork https://www.upwork.com/ (n.d.). [Online] [Last Accessed 19/09/15]

Wamba, S. F., \& Carter, L. (2013). Twitter adoption and use by SMEs: An empirical study. In System Sciences (HICSS), (January) 46th Hawaii International Conference, 2042-2049). IEEE. http://www.computer.org/csdl/proceedings/hicss/2013/4892/00/4892c042.pdf 